\title{
Mechanism of Phosphorus Enrichment in Dephosphorization Slag Produced Using the Technology of Integrating Dephosphorization and Decarburization
}

\author{
Haimeng Xue ${ }^{1}$, Jie Li ${ }^{1,2}$, Yunjin Xia ${ }^{1}$, Yong Wan ${ }^{1}$, Liangjun Chen ${ }^{1, *}$ and Changi Lv ${ }^{1}$ \\ 1 School of Metallurgical Engineering, Anhui University of Technology, Ma'anshan 243002, China; \\ xhm13957297289@163.com (H.X.); yejinlijie@163.com or 1sqlijie@126.com (J.L.); xyjsssss@aliyun.com (Y.X.); \\ wanyong0729@ahut.edu.cn or wanyong0729@163.com (Y.W.); lvchangji@163.com (C.L.) \\ 2 Key Lab of Metallurgical Emission Reduction \& Resources Recycling, Ministry of Education, \\ Ma'anshan 243002, China \\ * Correspondence: ljchen2021@ahut.edu.cn or ljchen2016@163.com; Tel.: +86-178-1213-1397
}

Citation: Xue, H.; Li, J.; Xia, Y.; Wan, Y.; Chen, L.; Lv, C. Mechanism of Phosphorus Enrichment in Dephosphorization Slag Produced Using the Technology of Integrating Dephosphorization and

Decarburization. Metals 2021, 11, 216. https://doi.org/10.3390/ met11020216

Academic Editor: Timo Fabritius

Received: 20 December 2020

Accepted: 21 January 2021

Published: 26 January 2021

Publisher's Note: MDPI stays neutral with regard to jurisdictional claims in published maps and institutional affiliations.

Copyright: (c) 2021 by the authors. Licensee MDPI, Basel, Switzerland. This article is an open access article distributed under the terms and conditions of the Creative Commons Attribution (CC BY) license (https:/ / creativecommons.org/licenses/by/ $4.0 /)$.

\begin{abstract}
In order to better understand and develop the technology of integrating dephosphorization and decarburization in a single converter (abbreviated as IDDSC), the relevant thermodynamic issues were discussed by calculation. Based on the thermodynamic calculation, the bridges between the phosphorus distribution ratio, temperature, and slag composition were constructed. Besides, the connections between the dephosphorization behavior and the microstructure of slag were also established by investigating four heats of hot metal smelt using IDDSC technology. As a result, the mechanism of phosphorus enrichment in the dephosphorization slag was revealed. Also, the results show that the dephosphorization efficiency increases gradually with increasing slag basicity. While the dephosphorization efficiency increases first and then decreases with the increase of FeO content in slag. There is a competition relationship between $\mathrm{P}_{2} \mathrm{O}_{5}$ and $\mathrm{FeO}$ in reacting with $\mathrm{CaO}$ and $\mathrm{SiO}_{2}$. When $\mathrm{CaO} / \mathrm{FeO}$ is relatively high, not enough $\mathrm{FeO}$ is provided. Thus $\mathrm{P}_{2} \mathrm{O}_{5}$ is in priority to react with $\mathrm{CaO}$ and $\mathrm{SiO}_{2}$ through $[3 n+2](\mathrm{CaO})+2 \mathrm{SiO}_{2}+n\left(\mathrm{P}_{2} \mathrm{O}_{5}\right)=n\left(3 \mathrm{CaO} \cdot \mathrm{P}_{2} \mathrm{O}_{5}\right)-2 \mathrm{CaO} \cdot \mathrm{SiO}_{2}(\mathrm{~s})$, generating $\mathrm{P}_{2} \mathrm{O}_{5}$-rich $n \mathrm{C}_{2} \mathrm{~S}-\mathrm{C}_{3} \mathrm{P}$ solid solution which promotes the removal of $[\mathrm{P}]$ from the hot metal. When $\mathrm{CaO} / \mathrm{FeO}$ is relatively low, $\mathrm{FeO}$ competes over $\mathrm{P}_{2} \mathrm{O}_{5}$ in reacting with $\mathrm{CaO}$ and $\mathrm{SiO}_{2}$ through $a(\mathrm{CaO})$ $+b\left(\mathrm{SiO}_{2}\right)+c(\mathrm{FeO})=a \mathrm{CaO} \cdot b \mathrm{SiO}_{2} \cdot c \mathrm{FeO}(\mathrm{s})$, generating $\mathrm{CaFeSiO}_{4}$ instead of $\mathrm{P}_{2} \mathrm{O}_{5}$-rich solid solution. As a consequence, the slag with low $\mathrm{CaO} / \mathrm{FeO}$ shows a poor dephosphorization ability.
\end{abstract}

Keywords: dephosphorization; IDDSC technology; $n \mathrm{C}_{2} \mathrm{~S}-\mathrm{C}_{3} \mathrm{P}$ solid solution; phosphorus enrichment

\section{Introduction}

Phosphorus is a detrimental element that is very likely to cause cold brittleness in steel. Different steels have different requirements for the range of phosphorus content in final products, yet most steels require phosphorus content to be limited to less than $0.045 \%$ and the phosphorus in the hot metal should be removed as much as possible in terms of steel quality. The technology of integrating dephosphorization and decarburization in a single converter (abbreviated as IDDSC) [1-3] is a technology of transferring the task of dephosphorization pretreatment from outside the converter to inside the converter by the means of dividing the smelting process into dephosphorization stage and decarburization stage inside the converter. The flow chart of IDDSC technology is shown in Figure 1. At the beginning of the dephosphorization stage, various slagging agents are added into the converter furnace for the purpose of desilication and dephosphorization. At the end of dephosphorization stage, part of the dephosphorization slag is poured out and the remaining part is modified into decarbonization slag by adding proper slagging agents. It is evident that the IDDSC technology retains the technical characteristics of the duplex converters without suffering from the heat loss caused by the transport of semi-steel from 
the dephosphorization furnace to the decarbonization converter. Besides, the IDDSC technology saves an extra dephosphorization station outside the steelmaking converter. Hence, it is considered as an energy-saving, low-cost, and efficient technology which attracts a lot of attention from metallurgists [4].

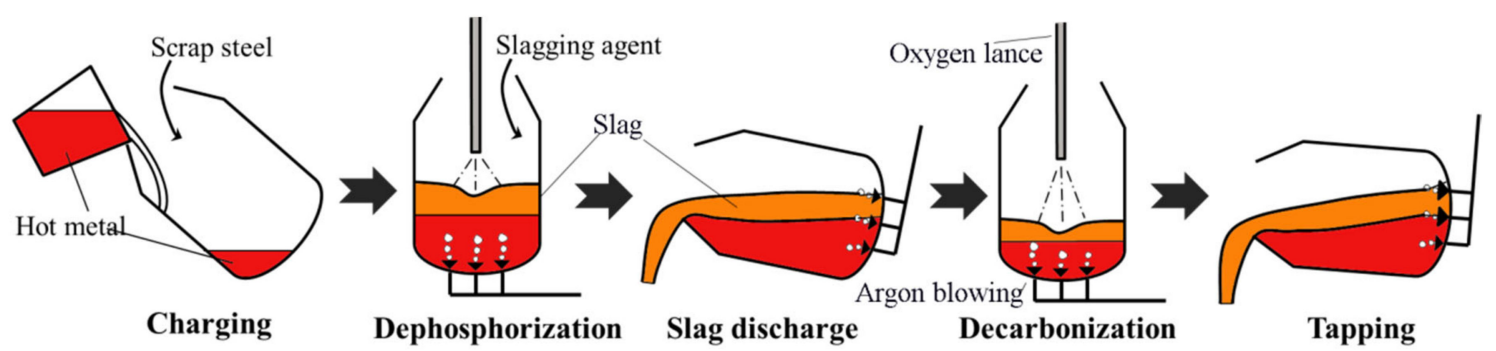

Figure 1. Flow chart of integrating dephosphorization and decarburization in a single converter (IDDSC) process.

The concept of integrating dephosphorization and decarburization in a single converter (IDDSC) was first put forward by Ogawa et al. It was named Multi-Refining Converter (abbreviated as MURC) and firstly tested in an 8-t experimental converter of Nippon Steel in $2001[5,6]$. It was reported that the IDDSC process may save $25 \%$ of slag volume [6]. Moreover, per ton of converter slag with a high temperature of around $1600{ }^{\circ} \mathrm{C}$ contains $1.5 \mathrm{GJ}$ of heat energy. Assuming that the ratio of slag to hot metal is 1:100, then the heat loss is calculated to be reduced by $3750 \mathrm{~kJ}$ for per ton of hot metal, which indicates a big potential for savings on energy. For this reason, this idea was developed into a technology of integrating dephosphorization and decarburization in a single converter for energy saving and is widely applied in Oita, Yawata, Muroran, and Kimitsu Steelworks of the Nippon Steel Corporation [7-11]. Inspired by these typical examples, a similar IDDSC method named "Slag-Remaining + Double-Slag" was proposed by Shougang Corporation in China, and it has been successfully applied on a large scale in the affiliated Qianan Steelworks and Shouqin Steelworks [12]. The duplex slag process was optimized in a basic oxygen furnace (BOF). After optimization, the phosphorus content in steel at the end of the oxygen blowing stage was controlled to levels as low as $0.0042 \%$ [13]. Twenty heats of industrial trials were carried out in an 80-t converter of Wuhan Iron and Steel Corporation (abbreviated as WISCO) by employing the IDDSC technology, resulting in a mean dephosphorization efficiency of $91 \%$, which is much higher than the efficiency $(82 \%)$ obtained in the previous process [1]. Fang et al. [14] applied the IDDSC technology on a 120-t steelmaking converter and studied the influence of the basicity and oxidizability of slag on the dephosphorization performance. Fifty heats of industrial tests were carried out by Li et al. by employing IDDSC technology in a 100-t converter. With a rise in oxygen consumption ratio from $20-30 \%$ to $30-50 \%$ during the period of dephosphorization and [C] content limited in the range of $0.1-0.2 \%$, the hit ratio of temperature increased from $86.3 \%$ to $92.3 \%$, and the hit ratio of $[\mathrm{P}]$ content increased from less than $50 \%$ to $92.3 \%$. This implies that the ability to control temperature and [P] content was significantly enhanced [3]. Wang et al. determined the optimal proportion for furnace burden and the optimal cut-off point between the dephosphorization stage and decarbonization stage [15], and investigated the slag forming route at both the dephosphorization and decarbonization stages during the production of medium phosphorus hot metal using IDDSC technology [2]. Although a lot of efforts have been put into developing IDDSC technology, most of the studies were focused on the technical aspect instead of the mechanism aspect.

To better understand the advantage and control principle of IDDSC technology, the IDDSC technology was deeply studied by a combination of technical analysis and mechanism exploration in the present paper. First, the essential points of operation for IDDSC technology were discussed based on the production practice. Then, the control target for the composition of dephosphorization slag in the IDDSC process was determined by thermodynamic calculation. Finally, the mechanism of phosphorus enrichment in the 
dephosphorization slag was studied by identifying and analyzing the typical dephosphorization slags in practical production. These researches provide an important reference for improving the IDDSC technology.

\section{Technical Details for the IDDSC Process}

The steelmaking converter used for this research has a nominal capacity of $70 \mathrm{t}$. At the beginning, 56-63 t of hot metal and 10-14.5 $\mathrm{t}$ of scrap steel are charged into the converter as the raw material for steelmaking. The converter is equipped with an oxygen lance coupled with a four-hole nozzle, and the oxygen supply intensity is in the range of $3.3-3.6 \mathrm{~m}^{3} /(\mathrm{t} \cdot \mathrm{min})$, with a blowing flow rate of $16,000 \mathrm{~m}^{3} / \mathrm{h}$ and a blowing pressure of $0.75-0.85 \mathrm{MPa}$. The Mach number is 1.98 and the outlet diameter is $42 \mathrm{~mm}$. Three double annular slot gas supply elements are used for blowing argon gas from the bottom. The argon flow rate ranges from 90 to $120 \mathrm{~m}^{3} / \mathrm{h}$ and the blowing pressure ranges from 0.2 to $0.4 \mathrm{MPa}$. The refractory of the converter lining is $\mathrm{MgO}-\mathrm{C}$ brick. The composition and temperature of the hot metal are shown in Table 1.

Table 1. Compositional content and temperature of the hot metal (wt.\%).

\begin{tabular}{cccccc}
\hline$[\mathrm{C}]$ & {$[\mathrm{Si}]$} & {$[\mathrm{Mn}]$} & {$[\mathrm{P}]$} & {$[\mathrm{S}]$} & Temperature of Hot Metal (K) \\
\hline $4.30-4.60$ & $0.50-0.60$ & $0.25-0.35$ & $0.120-0.140$ & $0.001-0.003$ & $1593-1613$ \\
\hline
\end{tabular}

The key of the IDDSC technology is the proper control of the lance position and blowing flow. Their control scheme is shown in Figure 2. A total amount of $2000-2600 \mathrm{~kg}$ of lime, $1000-1300 \mathrm{~kg}$ of light-burned dolomite, and $800-1000 \mathrm{~kg}$ of ore were added during the whole process of converter steelmaking. At the beginning of the dephosphorization stage when the oxygen lance is ignited, both the lance position and blowing flow rate are adjusted to a high level, accompanied with light burnt dolomite $(3 / 4)$ and ore $(1 / 3)$ addition, in order to form slag quickly and keep an atmosphere of high oxidizability. After slag formation, both the lance position and blowing flow rate are lowered to remove silicon and manganese from the hot metal. At the end of the dephosphorization stage before deslagging, both the lance position and blowing flow rate are elevated again to generate more $\mathrm{FeO}$ in the slag. In this way, the processes of dephosphorization and foaming slag were promoted, and the fully foamed slag is more easily poured out. After deslagging, lime (2/3) and light burnt dolomite $(1 / 4)$ are added to modify the remaining dephosphorization slag into decarbonization slag. At this point, a high blowing flow rate is necessary to accelerate slag formation and this point is considered to be the beginning of the decarbonization stage. After slag formation, blowing flow rate is decreased to a low level for decarbonization. One minute later, the remaining lime and ore are selectively added based on the actual smelting process, aimed at achieving the fine and accurate adjustment of slag composition. After decarbonization for about $10 \mathrm{~min}$, the decarbonization reaction weakens gradually. At this point, the lance position is elevated properly to accelerate slagging and avoid rephosphorization caused by slag drying. At the end of the decarbonization stage, the lance position is lowered while the blowing flow rate is increased to intensify the stirring action for the purpose of ensuring the homogenization of the composition and temperature of the molten steel. 


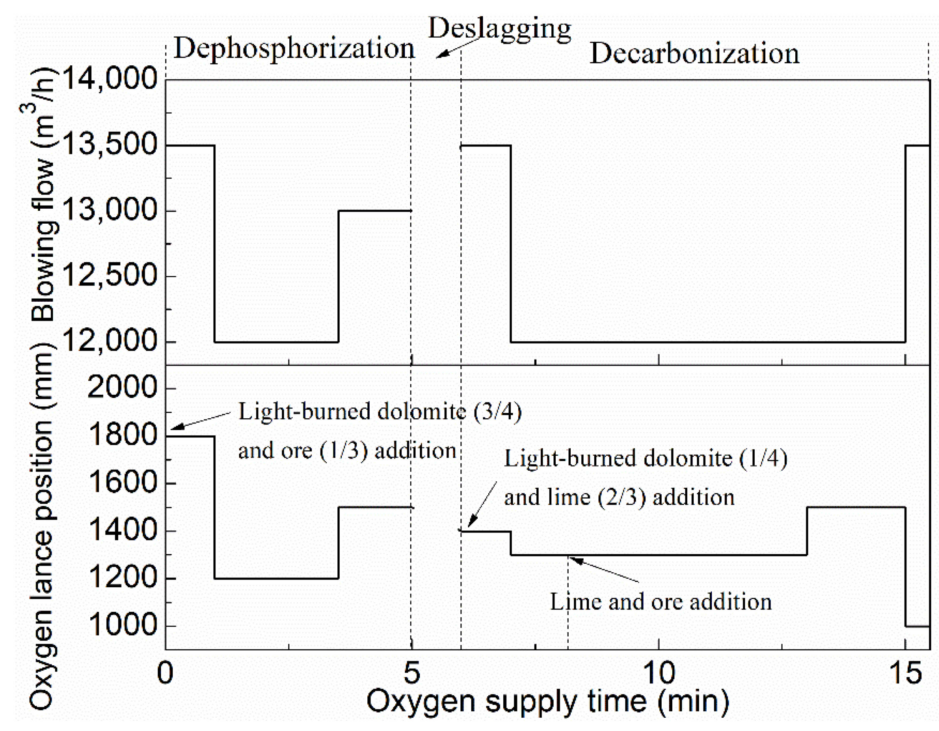

Figure 2. Control scheme of IDDSC process.

\section{Thermodynamic Calculations for Dephosphorization}

According to the previous literatures, the equilibrium distribution of phosphorus between the slag and hot metal follows a certain pattern as shown in Equation (1) [16].

$$
\lg (\% P) / a_{P}=2.5 \lg (\% \mathrm{TFe})+0.0715\{(\% \mathrm{CaO})+0.25(\% \mathrm{MgO})\}+7710.2 / \mathrm{T}-8.55
$$

where $a_{P}$ represents the activity of $[\mathrm{P}]$ in the hot metal, TFe represents the total amount of iron in slag.

$a_{P}$ can be calculated by Equations (2) and (3):

$$
\begin{gathered}
a_{P}=f_{P} \cdot[\% P] \\
\lg f_{P}=e_{P}^{C} \cdot[\% C]
\end{gathered}
$$

where $f_{P}$ represents the activity coefficient of $[\mathrm{P}], e_{P}^{C}$ represents the interaction coefficient between $[\mathrm{C}]$ and $[\mathrm{P}] . e_{P}^{C}$ can be obtained by Equation (4) as proposed by Tsukihashi [17].

$$
e_{P}^{C}=\frac{105.1}{T}+0.0723
$$

The phosphorus partition ratio between the slag and hot metal, $\mathrm{L}_{P}$, is defined as:

$$
\lg L_{P}=\lg (\% P) /[\% P]
$$

Through a series of mathematical transformation, the equation for phosphorus distribution ratio $\left(L_{P}\right)$ can be obtained as below:

$\lg L_{P}=2.5 \lg (\% \mathrm{TFe})+0.0715\{(\% \mathrm{CaO})+0.25(\% \mathrm{MgO})\}+7710.2 / \mathrm{T}-8.55+(105.1 / \mathrm{T}+0.0723)[\% \mathrm{C}]$

The slag is mainly composed of $\mathrm{MgO}, \mathrm{CaO}, \mathrm{SiO}_{2}$, iron oxides, and other minor components such as $\mathrm{MnO}, \mathrm{P}_{2} \mathrm{O}_{5}$, and $\mathrm{Al}_{2} \mathrm{O}_{3}$. Assuming that all iron oxides exist in the form of $\mathrm{FeO}$, the total amount of the minor components is $15 \%$, $(\mathrm{MgO})$ content in slag is $8.0 \%$, [C] content in the hot metal is 3.8\%, then Equation (6) can be converted into Equation (7).

$$
\lg L_{P}=2.5 \lg (\% \mathrm{FeO})+0.0715\left\{\frac{B}{1+B}(77-72 / 56(\% F e O))\right\}+8109.58 / T-8.4
$$

where $B$ is the basicity of slag, expressed as:

$$
\mathrm{B}=(\% \mathrm{CaO}) /\left(\% \mathrm{SiO}_{2}\right)
$$


According to Equation (7), the relationship between phosphorus distribution ratio $\left(L_{P}\right)$, temperature $(T)$, slag basicity $(B)$, and $\mathrm{FeO}$ content can be described in Figure 3. With the increase of $\mathrm{FeO}$ content, the phosphorus distribution ratio first increases and then decreases. And $\mathrm{FeO}$ content should be controlled in the range of $20-25 \%$ to obtain optimal dephosphorization efficiency. As seen in Figure 3a, the phosphorus distribution ratio shows an increasing tendency with the increase of basicity. As seen in Figure $3 b$, the phosphorus distribution ratio decreases notably with elevated temperature. This is consistent with the general viewpoint that low temperature facilitates dephosphorization of the hot metal $[18,19]$. Based on the discussion above, in order to obtain a good dephosphorization performance, $\mathrm{FeO}$ content in slag should be controlled in the range of $20-25 \%$, the slag basicity should be kept at a high level, while the temperature should be lowered as much as possible in the premise of satisfying fluidity.
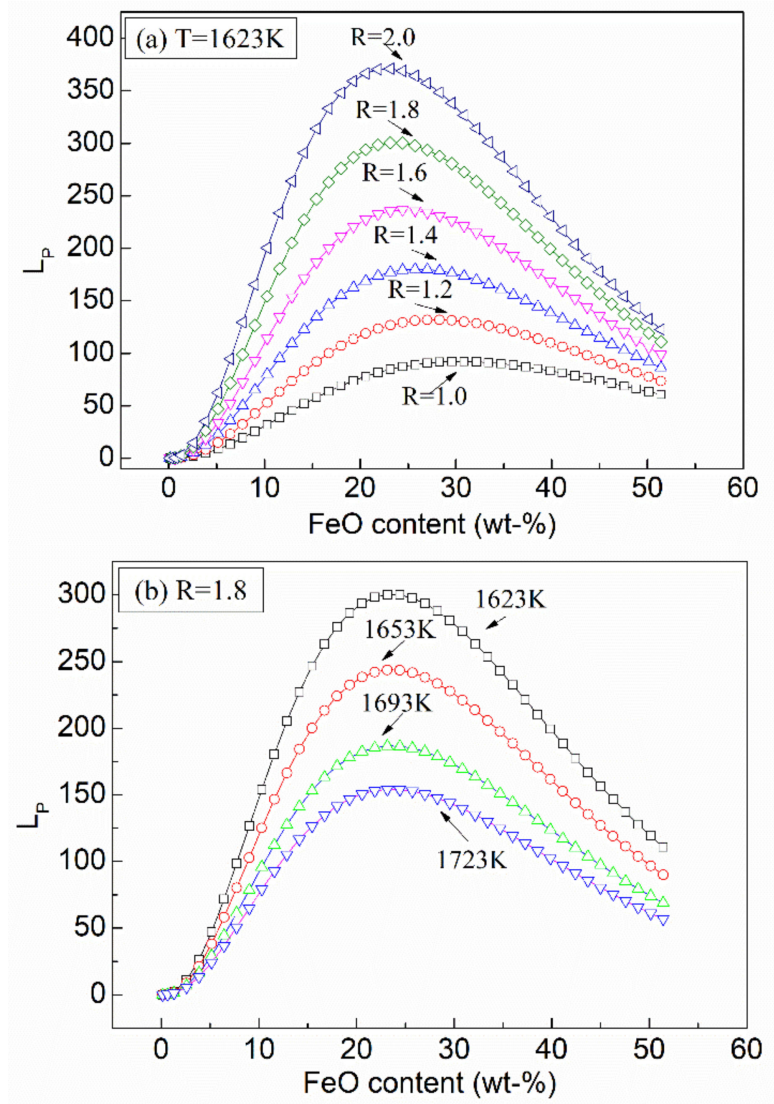

Figure 3. Changes of phosphorus distribution ratio with FeO content (a) temperature fixed at $1623 \mathrm{~K}$, various basicity; (b) basicity fixed at 1.8 , various temperatures.

\section{Sampling and Analysis}

In order to verify the calculated thermodynamic rules and to deduce the corresponding mechanism, four heats of the hot metal under the action of typical slag composition were produced by employing IDDSC technology. During the period of production, hot metal samples before and after dephosphorization were taken using a cylindrical immersion sampler and quenched in cold water quickly. To calculate the dephosphorization efficiency, the element concentrations in these hot metal samples were examined by inductively coupled plasma mass spectrometry (ICP-MS, Thermo Electron Corporation, Waltham, MA, USA, IRIS intrepid II). Slag samples were dipped using a long molybdenum rod and quenched in cold water quickly at the end of the dephosphorization stage. Each slag sample was divided into three parts. One part is examined by X-ray fluorescence (XRF, Thermo Scientific, ARLAdvant ${ }^{\prime} X$ Intellipower ${ }^{\mathrm{TM}}$ 3600) to determine chemical composition. Another part is evaluated by X-ray diffraction to identify phase type. The X-ray diffraction 
$(\mathrm{XRD})$ is performed on a diffractometer (Bruker, D8ADVANCE, $\mathrm{Cu} \mathrm{K} \alpha$ radiation) between $5^{\circ}$ and $85^{\circ}(2 \theta)$ by steps of $0.01^{\circ}$. The tube voltage is set as $60 \mathrm{kV}$ and the current is set as $60 \mathrm{~mA}$. The left part is prepared as metallographic samples by a series of operations, such as mounting, grinding, polishing, and gold-spraying. The metallographic samples were evaluated under a scanning electron microscope (SEM, JSM-6490LV, Japan) equipped with energy dispersive spectrometry (EDS, INCA, OXFORD, England).

\section{Experimental Results}

\subsection{Compositions of Slag and Hot Metal}

The compositions of the hot metal before and after dephosphorization are shown in Table 2. The composition of slag detected by XRF analysis and the dephosphorization efficiency calculated based on ICP analysis results are shown in Table 3. The dephosphorization efficiency $\left(\eta_{P}\right)$ is calculated by the following Equation:

$$
\eta_{\mathrm{P}}=\frac{[P]_{\mathrm{B}}-[P]_{\mathrm{A}}}{[P]_{\mathrm{B}}} \times 100 \%
$$

where $[P]_{B}$ represents the $[P]$ content in hot metal before dephosphorization and $[P]_{A}$ represents the $[\mathrm{P}]$ content in hot metal after dephosphorization.

Table 2. Compositions of hot metal before and after dephosphorization.

\begin{tabular}{cccccccc}
\hline Heat No. & Sampling Position & $\mathbf{C}$ & $\mathbf{S i}$ & $\mathbf{M n}$ & $\mathbf{P}$ & $\mathbf{S}$ & $\begin{array}{c}\text { Dephosphorization } \\
\text { Efficiency (\%) }\end{array}$ \\
& & & & & & \\
\multirow{2}{*}{$\mathbf{1}$} & Before dephosphorization & 4.37 & 0.55 & 0.30 & 0.125 & 0.028 & $28.1 \%$ \\
& After dephosphorization & 2.78 & 0.01 & 0.04 & 0.0899 & 0.024 & \\
\multirow{2}{*}{} & Before dephosphorization & 4.42 & 0.54 & 0.32 & 0.136 & 0.026 & $45 \%$ \\
& After dephosphorization & 2.51 & 0.01 & 0.060 & 0.0748 & 0.020 & \\
\multirow{3}{*}{$\mathbf{4}$} & Before dephosphorization & 4.56 & 0.57 & 0.27 & 0.132 & 0.023 & $51.4 \%$ \\
& After dephosphorization & 2.86 & 0.01 & 0.070 & 0.0641 & 0.019 & \\
& Before dephosphorization & 4.52 & 0.53 & 0.25 & 0.137 & 0.023 & $28.1 \%$ \\
\hline
\end{tabular}

Table 3. Slag composition and dephosphorization efficiency.

\begin{tabular}{ccccccccc}
\hline Heat No. & $\mathbf{S i O}_{\mathbf{2}}$ & $\mathbf{C a O}$ & $\mathbf{F e O}$ & $\mathbf{M g O}$ & $\mathbf{M n O}$ & $\mathbf{P}_{\mathbf{2}} \mathbf{O}_{\mathbf{5}}$ & Basicity & Dephosphorization Efficiency (\%) \\
\hline $\mathbf{1}$ & 25.0 & 25.2 & 24.5 & 3.6 & 8.6 & 2.7 & 1.01 & 28.1 \\
$\mathbf{2}$ & 22.8 & 35.7 & 20.1 & 4.2 & 5.0 & 4.8 & 1.56 & 45 \\
$\mathbf{3}$ & 20.9 & 36.8 & 20.7 & 6.5 & 3.3 & 3.5 & 1.76 & 51.4 \\
$\mathbf{4}$ & 17.5 & 22.9 & 31.4 & 3.8 & 5.7 & 2.2 & 1.31 & 22.9 \\
\hline
\end{tabular}

As seen in Table 3, the slags in Heat 2 and Heat 3 with appropriate FeO content (in the range of $20-25 \%$ according to the thermodynamic calculation in Section 3 and relatively high basicity (1.56 and 1.76, respectively) have high dephosphorization efficiency ( $45 \%$ and $51.4 \%$, respectively). The slag in Heat 1 with relatively low basicity (1.01) has a low dephosphorization efficiency (28.1\%). The slag in Heat 4 with relatively high FeO content (31.4\%) also possesses a low dephosphorization efficiency (22.9\%). It should be noted that the average $\mathrm{P}$ content in the slags was calculated to be in the range of $1-2 \%$. No $\mathrm{CaF}_{2}$ was added in the dephosphorization slags to avoid the generation of poisonous gases such as $\mathrm{AlF}_{3}(\mathrm{~g}), \mathrm{SiF}_{4}(\mathrm{~g})$, or $\mathrm{CaF}_{2}(\mathrm{~g})[20]$.

\subsection{Microsturcture of Dephosphorizaiton Slag}

The XRD pattern of the slag with a relatively low basicity in Heat 1 after dephosphorization is shown in Figure 4. It shows that the dephosphorization slag consists of a great deal of $\mathrm{CaFeSiO}_{4}$ and a little $\mathrm{Fe}_{3} \mathrm{O}_{4}$. The microscopic morphology of the slag and 
the corresponding EDS results are shown in Figure 5 and Table 4, respectively. The slag is composed of a massive grey coralloidal phase and a few white blocky phases. Combining the $\mathrm{XRD}$ analysis result with the fact that the grey phase is mainly composed of $\mathrm{Ca}, \mathrm{Si}, \mathrm{Fe}$, and $\mathrm{O}$, the grey phase can be identified as $\mathrm{CaFeSiO}_{4}$. The phosphorus content keeps stable in the grey phase and in the average phosphorus range (1-2\%) of slag. This implies that the phosphorus element is evenly distributed in the grey phase without enrichment. The white phase is mainly composed of $\mathrm{Fe}$ and $\mathrm{O}$, thus is identified as $\mathrm{Fe}_{3} \mathrm{O}_{4}$ combined with the XRD analysis result.

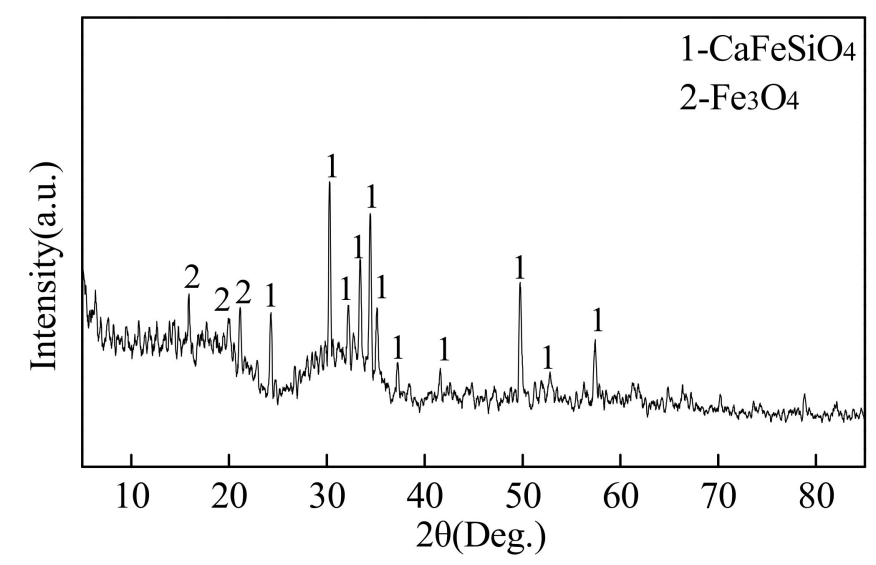

Figure 4. XRD pattern of dephosphorization slag in Heat 1.

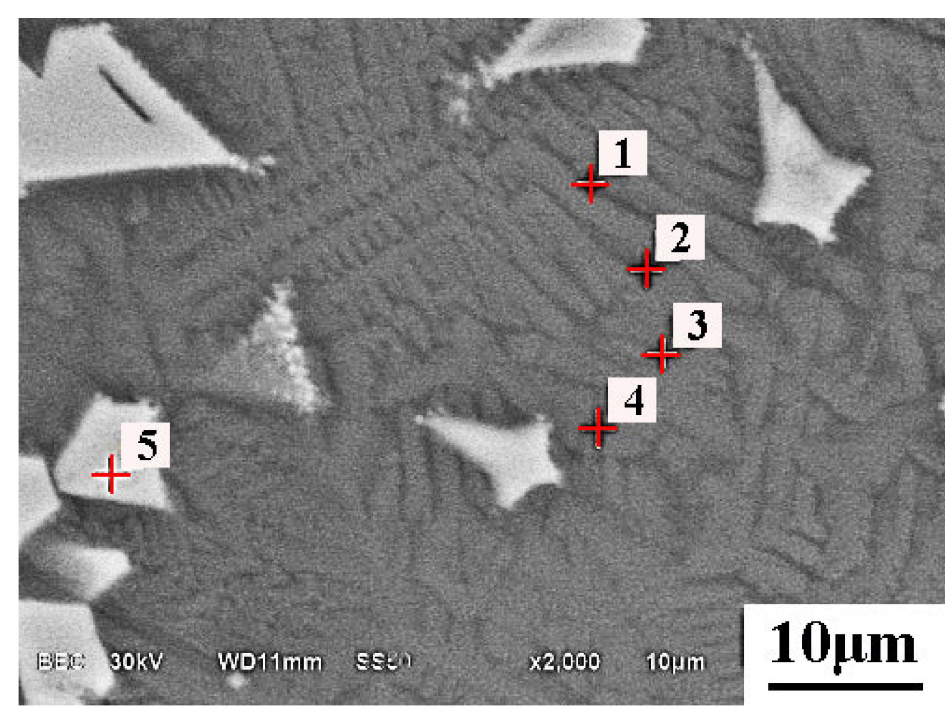

Figure 5. Scanning electron microscope (SEM) micrograph (backscattered electron) of the dephosphorization slag in Heat 1.

Table 4. Energy dispersive spectrometry (EDS) analysis results (wt.\%) of dephosphorization slag in Heat 1 corresponding to Figure 5.

\begin{tabular}{ccccccccc}
\hline Collected Position & Color & Ca & Si & Fe & $\mathbf{P}$ & $\mathbf{M g}$ & $\mathbf{M n}$ & $\mathbf{O}$ \\
\hline Point 1 & Grey & 21.5 & 14.2 & 14.5 & 1.74 & 1.7 & 6.7 & 39.7 \\
Point 2 & Grey & 21.0 & 14.4 & 14.6 & 1.76 & 1.8 & 6.6 & 39.8 \\
Point 3 & Grey & 21.0 & 13.7 & 14.9 & 1.59 & 2.6 & 7.7 & 38.5 \\
Point 4 & Grey & 20.6 & 13.2 & 15.4 & 1.52 & 2.4 & 7.5 & 39.4 \\
Point 5 & White & 3.54 & 1.7 & 37.0 & - & 2.2 & 9.4 & 46.2 \\
\hline
\end{tabular}


The XRD pattern of the slag with proper $\mathrm{FeO}$ content and relatively high basicity in Heat 2 is shown in Figure 6. It can be seen that the slag contains $\mathrm{Ca}_{14.92}\left(\mathrm{PO}_{4}\right)_{2.35}\left(\mathrm{SiO}_{4}\right)_{5.65}$ (abbreviated as $n$ C3P C2S), $\mathrm{Ca}_{2} \mathrm{Fe}_{2} \mathrm{O}_{5}$, and $\left(\mathrm{Mg}_{1.56} \mathrm{Fe}_{0.39} \mathrm{Ca}_{0.05}\right) \mathrm{Si}_{2} \mathrm{O}_{6}$. The microscopic morphology of the slag and the corresponding EDS results are shown in Figure 7 and Table 5, respectively. The slag is composed of the light grey dendrites, the dark grey phase embedded in the light grey phase, and a small quantity of black phase. The dark grey phase is mainly composed of $\mathrm{Ca}, \mathrm{Si}$, and $\mathrm{O}$ elements. It should be noted that the phosphorus content in the dark grey phase is higher than the average value (1-2\%). This implies that phosphorus enriches in the dark grey phase. Hence, the dark grey phase is recognized as P-rich $n \mathrm{C} 3 \mathrm{C} 2 \mathrm{~S}$. The light grey dendrite is mainly composed of $\mathrm{Ca}, \mathrm{Fe}$, and $\mathrm{O}$ elements, and, thus, is identified as $\mathrm{Ca}_{2} \mathrm{Fe}_{2} \mathrm{O}_{5}$ combined with the $\mathrm{XRD}$ analysis result. The most obvious trait of the dark phase lies in its high concentration of $\mathrm{Mg}$. This indicates that the dark phase is $\left(\mathrm{Mg}_{1.56} \mathrm{Fe}_{0.39} \mathrm{Ca}_{0.05}\right) \mathrm{Si}_{2} \mathrm{O}_{6}$ combined with the XRD analysis result.

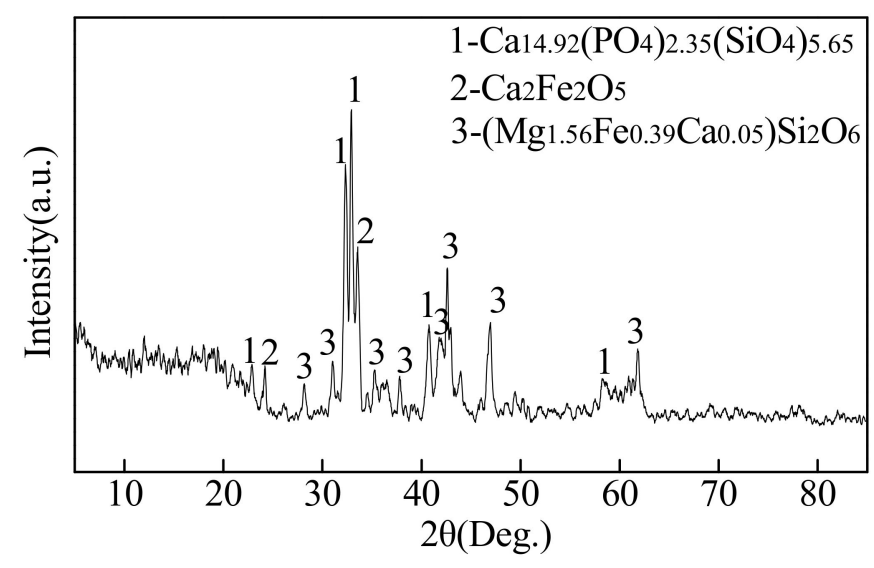

Figure 6. XRD pattern of dephosphorization slag in Heat 2.

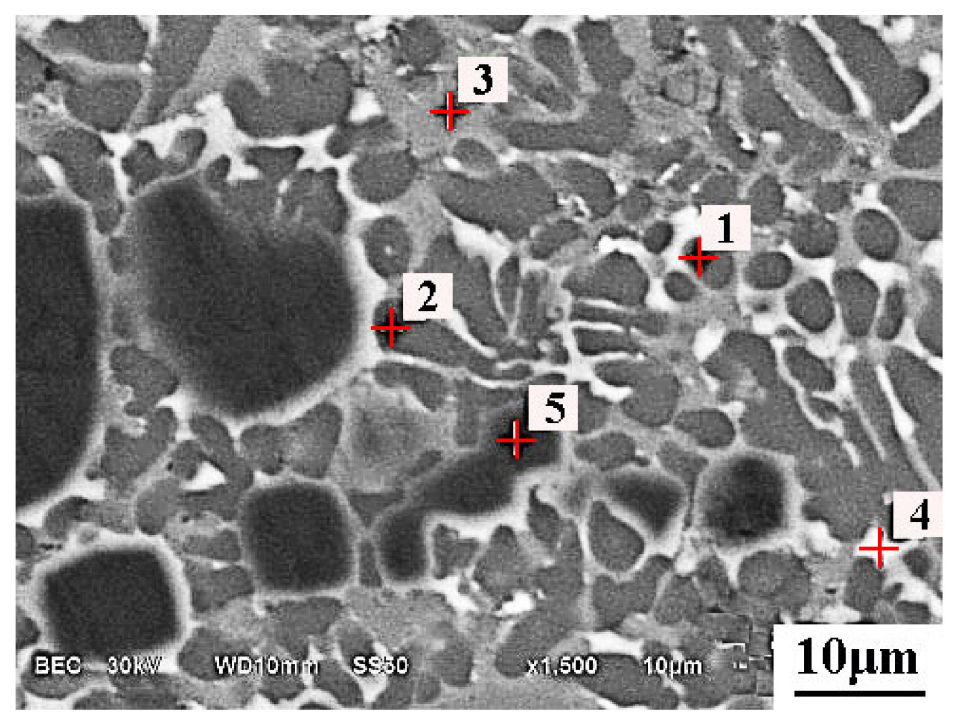

Figure 7. SEM micrograph (backscattered electron) of the dephosphorization slag in Heat 2. 
Table 5. EDS analysis results (wt.\%) of dephosphorization slag in Heat 2 corresponding to Figure 7.

\begin{tabular}{ccccccccc}
\hline Collected Position & Color & Ca & Si & Fe & $\mathbf{P}$ & $\mathbf{M g}$ & $\mathbf{M n}$ & $\mathbf{O}$ \\
\hline Point 1 & Dark grey & 43.02 & 9.24 & 8.04 & 2.60 & - & 0.81 & 36.29 \\
Point 2 & Dark grey & 38.85 & 8.72 & 9.20 & 2.60 & 1.19 & 1.13 & 38.31 \\
Point 3 & Light grey & 45.18 & 0.80 & 15.50 & 0.48 & - & 4.00 & 34.04 \\
Point 4 & Light grey & 35.40 & 2.06 & 17.99 & 0.76 & 1.67 & 2.02 & 40.1 \\
Point 5 & Black & 10.21 & 2.27 & 16.76 & - & 31.88 & 3.11 & 35.77 \\
\hline
\end{tabular}

The XRD pattern of the slag with similar FeO content and higher basicity in Heat 3 (compared with that in Heat 2) is shown in Figure 8. It shows that the slag consists of $n \mathrm{C} 3 \mathrm{P}$ C2S and $\left(\mathrm{Mg}_{1.56} \mathrm{Fe}_{0.39} \mathrm{Ca}_{0.05}\right) \mathrm{Si}_{2} \mathrm{O}_{6}$. The microscopic morphology of the slag and the corresponding EDS results are shown in Figure 9 and Table 6, respectively. The slag is composed of dark grey phase, light grey phase, and a little black phase. The dark grey phase is mainly composed of $\mathrm{Ca}, \mathrm{Si}$, and $\mathrm{O}$ elements. In addition, the dark grey phase contains $3.8 \%$ of phosphorus, which is much higher than the average value $(1-2 \%)$ in slag. Therefore, the dark grey phase is recognized as $n \mathrm{C} 3 \mathrm{P}$ C2S. The light grey phase is identified as $\left(\mathrm{Mg}_{1.56} \mathrm{Fe}_{0.39} \mathrm{Ca}_{0.05}\right) \mathrm{Si}_{2} \mathrm{O}_{6}$ based on its trait of containing a high concentration of $\mathrm{Mg}$ and Fe. The black phase mainly contains $\mathrm{Ca}$ and $\mathrm{O}$ and is thus thought to be $\mathrm{CaO}$.

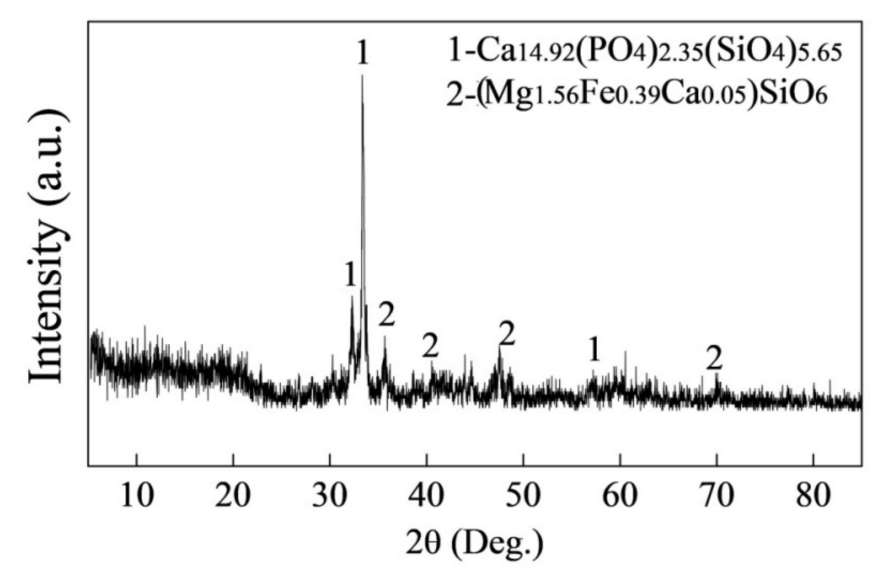

Figure 8. XRD pattern of dephosphorization slag in Heat 3.

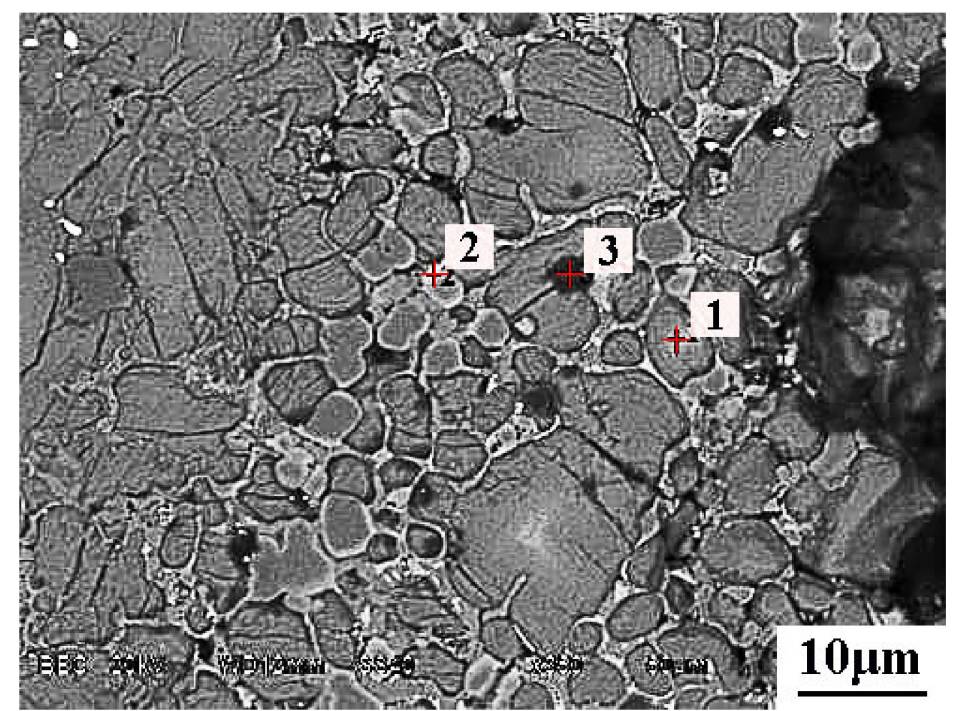

Figure 9. SEM micrograph (backscattered electron) of the dephosphorization slag in Heat 3. 
Table 6. EDS analysis results (wt.\%) of dephosphorization slag in Heat 3 corresponding to Figure 9.

\begin{tabular}{ccccccccc}
\hline Collected Position & Color & Ca & Si & Fe & P & Mg & Mn & O \\
\hline Point 1 & Dark grey & 38.1 & 12.3 & - & 3.8 & - & - & 45.8 \\
Point 2 & Light grey & - & 5.0 & 30.5 & - & 33.8 & 6.1 & 24.6 \\
Point 3 & Black & 56.23 & - & - & - & - & - & 27.32 \\
\hline
\end{tabular}

The XRD pattern of the slag containing relatively high $\mathrm{FeO}$ concentration in Heat 4 is shown in Figure 10. It can be seen that the slag consists of $\mathrm{CaFeSiO}_{4}$ and $\mathrm{Fe}_{3} \mathrm{O}_{4}$. The microscopic morphology of the slag and the corresponding EDS results are shown in Figure 11 and Table 7, respectively. The slag is composed of light grey coralloidal phase, white dendritic or blocky phase, and grey slag matrix. The grey phase is mainly composed of $\mathrm{Ca}, \mathrm{Si}, \mathrm{Fe}$, and $\mathrm{O}$, thus is identified as $\mathrm{CaFeSiO}_{4}$. The white phase is mainly composed of Fe and $\mathrm{O}$, thus is identified as $\mathrm{Fe}_{3} \mathrm{O}_{4}$.

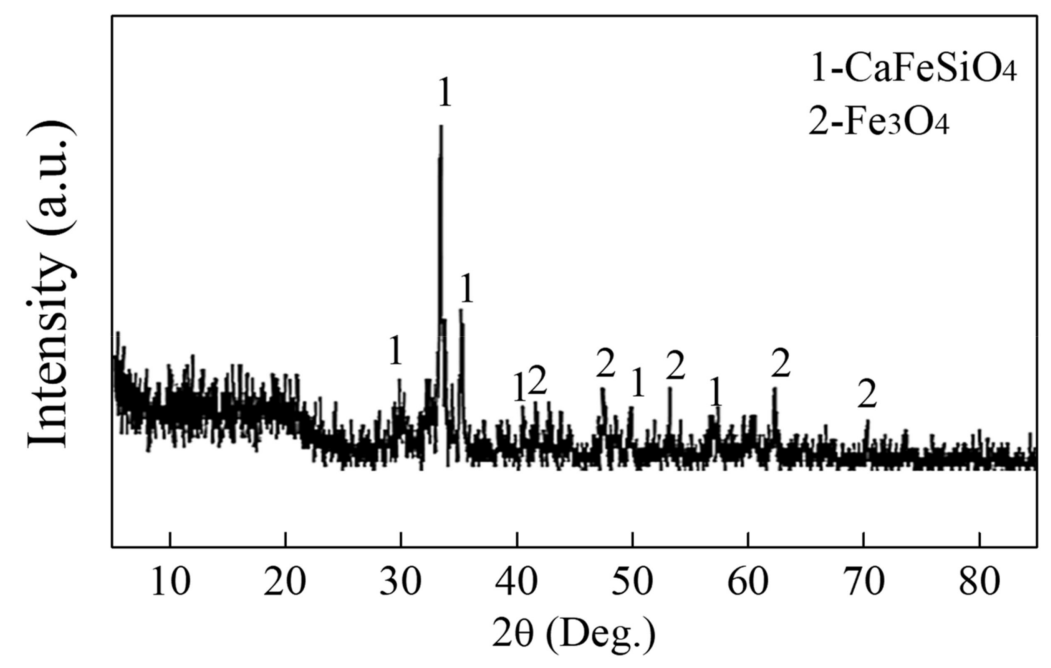

Figure 10. XRD pattern of dephosphorization slag in Heat 4.

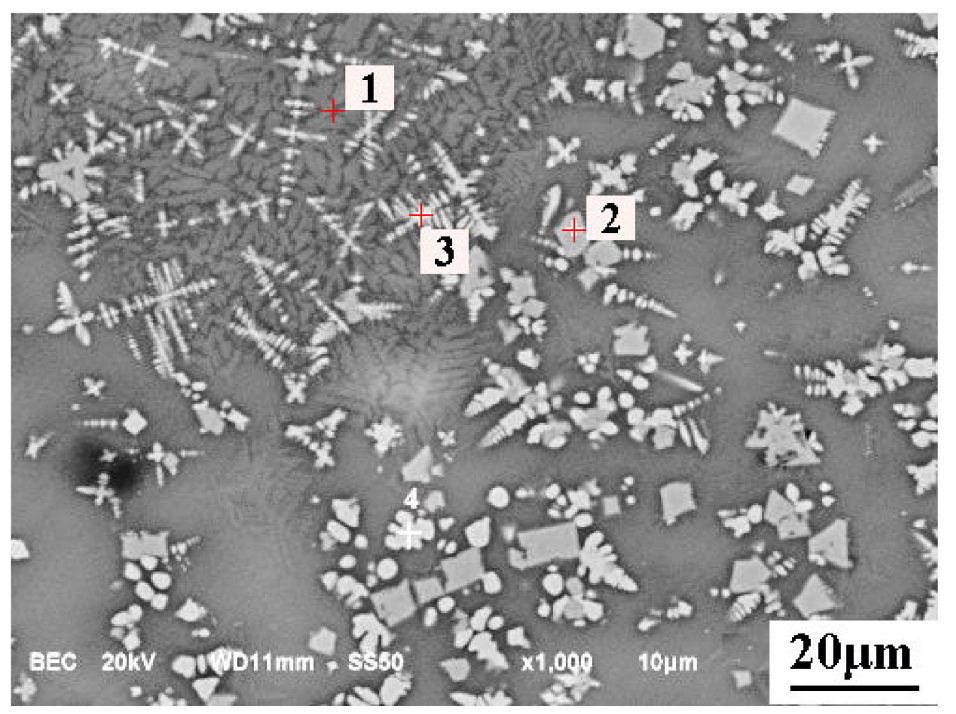

Figure 11. SEM micrograph (backscattered electron) of the dephosphorization slag in Heat 4. 
Table 7. EDS analysis results (wt.\%) of dephosphorization slag in Heat 4 corresponding to Figure 11.

\begin{tabular}{ccccccccc}
\hline Collected Position & Color & Ca & Si & Fe & $\mathbf{P}$ & $\mathbf{M g}$ & $\mathbf{M n}$ & $\mathbf{O}$ \\
\hline Point 1 & Light grey & 14.48 & 13.22 & 18.13 & 1.88 & 1.74 & 8.9 & 35.51 \\
Point 2 & White & 2.41 & 1.59 & 32.03 & - & 1.49 & 8.27 & 21.71 \\
Point 3 & White & 4.67 & 3.32 & 45.36 & 0.58 & 1.91 & 8.31 & 26.18 \\
Point 4 & White & 1.72 & 1.16 & 54.99 & - & 1.67 & 8.37 & 23.48 \\
\hline
\end{tabular}

\section{Discussions}

The dephosphorization slags in Heats 1-3 contain similar FeO content but have quite different basicity. When the FeO content is fixed within the scope of $22.3 \pm 2.2 \%$, the relationship between dephosphorization efficiency and slag basicity can be established and plotted in Figure 12. The dephosphorization efficiency shows an increasing tendency with the rise of slag basicity, which is consistent with the calculated laws in Section 3. This indicates that relatively high basicity is an essential condition for good dephosphorization performance.

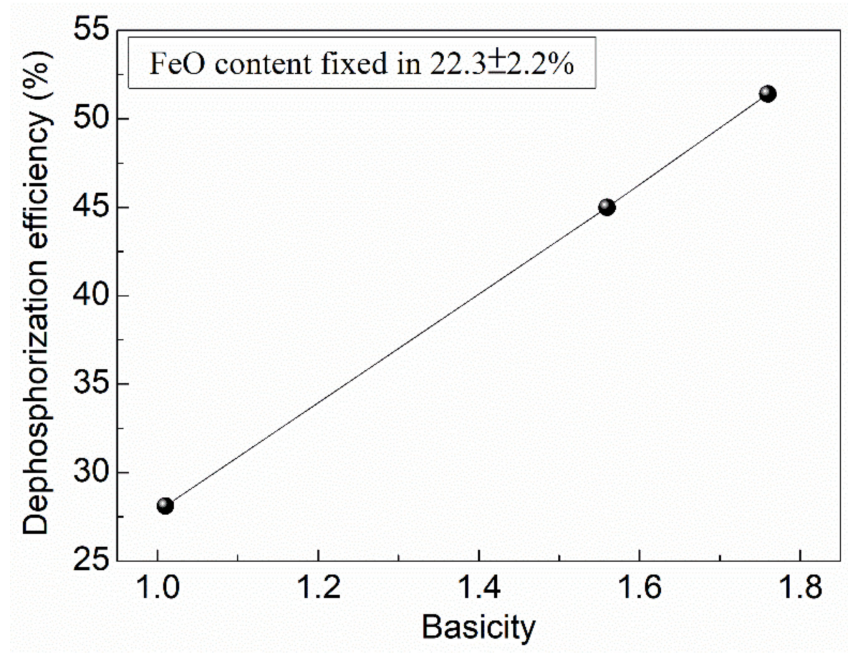

Figure 12. Relationship between dephosphorization efficiency and slag basicity.

As shown in Table 3, the dephosphorization slag containing a high concentration of $\mathrm{FeO}$ out of the optimal scope (20-25\% as mentioned in Section 3) in Heat 4 has a low dephosphorization efficiency of $22.9 \%$. This infers that too much FeO may inhibit the dephosphorization reaction.

Based on the molecular theory of molten slag, [P], [Si], [Mn], and [C] in the hot metal will be oxidized by FeO in slag at the interface between the slag and hot metal, as expressed below:

$$
\begin{gathered}
5(\mathrm{FeO})+2[\mathrm{P}]=5[\mathrm{Fe}]+\left(\mathrm{P}_{2} \mathrm{O}_{5}\right) \\
2(\mathrm{FeO})+[\mathrm{Si}]=2[\mathrm{Fe}]+\left(\mathrm{SiO}_{2}\right) \\
(\mathrm{FeO})+[\mathrm{Mn}]=[\mathrm{Fe}]+(\mathrm{MnO}) \\
(\mathrm{FeO})+[\mathrm{C}]=[\mathrm{Fe}]+\mathrm{CO}(\mathrm{g})
\end{gathered}
$$

[Si], $[\mathrm{Mn}]$, and $[\mathrm{C}]$ have a strong reductibility and thus compete with $[\mathrm{P}]$ to combine with the oxygen of FeO within slag by Reactions (11), (12), and (13), respectively. Therefore, the oxidation of [Si], [Mn], and [C] take place during the dephosphorization process, weakening the dephosphorization reaction and, thus, leading to an obvious reduce in [Si], [Mn], and [C] content as shown in Table 2.

The generated $\mathrm{P}_{2} \mathrm{O}_{5}$ is very likely to gather in $\mathrm{nC} 2 \mathrm{~S}-\mathrm{C} 3 \mathrm{P}$ solid solution by the means of combining with $\mathrm{CaO}$ and $\mathrm{SiO}_{2}$ in slag, as expressed by Formula (14). This process 
decreases the activity of $\mathrm{P}_{2} \mathrm{O}_{5}$ in the liquid part of slag, whereby promoting the progress of Reaction (10) which further facilitates the removal of $[\mathrm{P}]$ from the hot metal to slag.

$$
[3 n+2](\mathrm{CaO})+2 \mathrm{SiO}_{2}+n\left(\mathrm{P}_{2} \mathrm{O}_{5}\right)=n\left(3 \mathrm{CaO} \cdot \mathrm{P}_{2} \mathrm{O}_{5}\right)-2 \mathrm{CaO} \cdot \mathrm{SiO}_{2}(\mathrm{~s})
$$

For Heats 2 and 3 with appropriate $\mathrm{FeO}$ content and relatively high basicity $(\mathrm{CaO} / \mathrm{FeO}$ is about 1.8$)$, the dephosphorization efficiency was relatively high $(45 \%$ and $51.4 \%$, respectively) and $\mathrm{P}_{2} \mathrm{O}_{5}$-rich $n$ C2S-C3P $\left(\mathrm{Ca}_{14.92}\left(\mathrm{PO}_{4}\right)_{2.35}\left(\mathrm{SiO}_{4}\right)_{5.65}\right)$ was detected in the dephosphorization slag. This proves the deduction mentioned above that the generation of $n \mathrm{C} 2 \mathrm{~S}-\mathrm{C} 3 \mathrm{P}$ derived from Reaction (14) facilitates the removal of [P] from the hot metal to slag.

For Heat 1 with relatively low basicity and Heat 4 with relatively high $\mathrm{FeO}$, no $\mathrm{P}_{2} \mathrm{O}_{5}$ rich $n \mathrm{C} 2 \mathrm{~S}-\mathrm{C} 3 \mathrm{P}$ is formed in the slag and, thus, the dephosphorization efficiency is low ( $28.1 \%$ and $22.9 \%$, respectively). The low basicity or high $\mathrm{FeO}$ content of the slag in Heat 1 and 4 mean a relatively low $\mathrm{CaO} / \mathrm{FeO}$ ratio (1.03 and 0.73 , respectively). Under this condition, $\mathrm{FeO}$ plays a leading role between $\mathrm{CaO}$ and $\mathrm{FeO}$. Hence, the massive $\mathrm{FeO}$ is very likely to react with $\mathrm{CaO}$ and $\mathrm{SiO}_{2}$ to generate $a \mathrm{CaO} \cdot b \mathrm{SiO}_{2} \cdot c \mathrm{FeO}$ solid solution as expressed by Reaction (15). This process consumes the $\mathrm{CaO}$ and $\mathrm{SiO}_{2}$ that could have combined with $\mathrm{P}_{2} \mathrm{O}_{5}$ by Reaction (13). For this reason, generation of $n$ C2S-C3P is inhibited. This conjecture can be proved by the fact that $\mathrm{CaFeSiO}_{4}\left(a \mathrm{CaO} \cdot b \mathrm{SiO}_{2} \cdot c \mathrm{FeO}\right)$ and $\mathrm{Fe}_{3} \mathrm{O}_{4}$ were detected instead of $\mathrm{Ca}_{14.92}\left(\mathrm{PO}_{4}\right)_{2.35}\left(\mathrm{SiO}_{4}\right)_{5.65}(n \mathrm{C} 2 \mathrm{~S}-\mathrm{C} 3 \mathrm{P})$ in the slags of Heat 1 and Heat 4.

$$
a(\mathrm{CaO})+b\left(\mathrm{SiO}_{2}\right)+c(\mathrm{FeO})=a \mathrm{CaO} \cdot b \mathrm{SiO}_{2} \cdot c \mathrm{FeO}(\mathrm{s})
$$

Based on the discussions above, the interaction mechanism can be deduced, as shown in Figure 13. Firstly, $[\mathrm{P}]$ in hot metal is oxidized by $\mathrm{FeO}$ in slag to generate $\mathrm{P}_{2} \mathrm{O}_{5}$. There is a competition relationship between the generated $\mathrm{P}_{2} \mathrm{O}_{5}$ and the already existing $\mathrm{FeO}$ attributed to their similar thermodynamic property. When $\mathrm{CaO} / \mathrm{FeO}$ is relatively high (that is, $\mathrm{FeO}$ content is low), $\mathrm{FeO}$ loses in the competition. As a consequence, $\mathrm{P}_{2} \mathrm{O}_{5}$ instead of $\mathrm{FeO}$ combines with $\mathrm{CaO}$ and $\mathrm{SiO}_{2}$ to generate $n \mathrm{C} 2 \mathrm{~S}-\mathrm{C} 3 \mathrm{P}$ solid solution, accelerating the removal of $[\mathrm{P}]$ from the hot metal. When $\mathrm{CaO} / \mathrm{FeO}$ is relatively low (that is, $\mathrm{FeO}$ content is high), $\mathrm{FeO}$ wins in the competition. Therefore, $\mathrm{FeO}$ instead of $\mathrm{P}_{2} \mathrm{O}_{5}$ combines with $\mathrm{CaO}$ and $\mathrm{SiO}_{2}$ to generate $\mathrm{CaFeSiO}_{4}$, resulting in poor dephosphorization performance of slag.

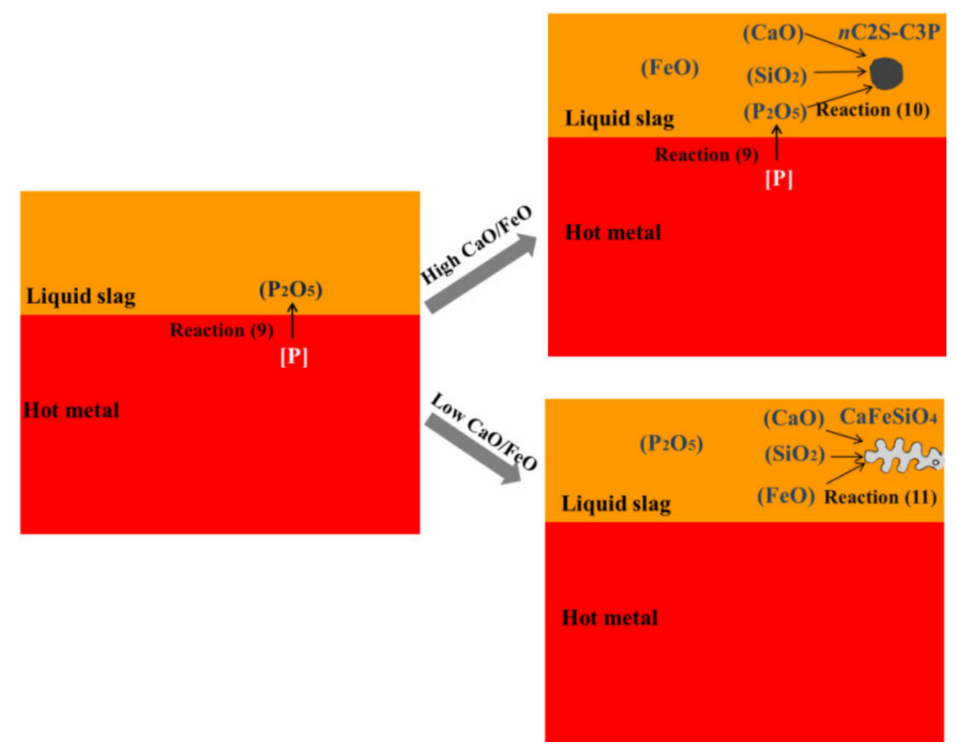

Figure 13. Interaction mechanism between the slag and hot metal for dephosphorization.

\section{Conclusions}

In the present paper, technical details for the IDDSC process were introduced, the relationship between phosphorus distribution ratio $\left(L_{\mathrm{P}}\right)$, temperature $(T)$, and slag com- 
position was established via thermodynamic calculations. In addition, the enrichment mechanism of $P$ in solid solution was deduced. Through research, some key conclusions were drawn as below:

1. The relationship between phosphorus distribution ratio $\left(L_{P}\right)$, temperature $(T)$, and slag composition can be presented as:

$$
\lg L_{\mathrm{P}}=2.5 \lg (\% \mathrm{FeO})+0.0715\left\{\frac{\mathrm{R}}{1+\mathrm{R}}(77-72 / 56(\% \mathrm{FeO}))\right\}+8109.58 / T-8.4
$$

2. In order to obtain optimal dephosphorization efficiency, the FeO content in slag should be limited in the range of $20-25 \%$, the slag basicity should be elevated to a high level, while the temperature should be lowered as much as possible in the premise of ensuring required fluidity.

3. For the dephosphorization slag containing proper $\mathrm{FeO}$ content and having relatively high basicity, $n$ C2S-C3P solid solution generates and gathers phosphorus, which promotes the removal of phosphorus from the hot metal. For the dephosphorization slag having a relatively low basicity or containing a relatively high $\mathrm{FeO}$, no $\mathrm{P}_{2} \mathrm{O}_{5}$-rich $n \mathrm{C} 2 \mathrm{~S}-\mathrm{C} 3 \mathrm{P}$ generates and, thus, the dephosphorization efficiency is low.

4. There is a competition relationship between $\mathrm{P}_{2} \mathrm{O}_{5}$ and $\mathrm{FeO}$ in reacting with $\mathrm{CaO}$ and $\mathrm{SiO}_{2}$. When $\mathrm{CaO} / \mathrm{FeO}$ is relatively high, $\mathrm{P}_{2} \mathrm{O}_{5}$ is in priority to combine with $\mathrm{CaO}$ and $\mathrm{SiO}_{2}$ to generate $n \mathrm{C} 2 \mathrm{~S}-\mathrm{C} 3 \mathrm{P}$ solid solution by $[3 n+2](\mathrm{CaO})+2 \mathrm{SiO}_{2}+n\left(\mathrm{P}_{2} \mathrm{O}_{5}\right)=$ $n\left(3 \mathrm{CaO} \cdot \mathrm{P}_{2} \mathrm{O}_{5}\right)-2 \mathrm{CaO} \cdot \mathrm{SiO}_{2}(\mathrm{~s})$, which facilitates the removal of $[\mathrm{P}]$ from the hot metal. When $\mathrm{CaO} / \mathrm{FeO}$ is relatively low, $\mathrm{FeO}$ instead of $\mathrm{P}_{2} \mathrm{O}_{5}$ is more likely to react with $\mathrm{CaO}$ and $\mathrm{SiO}_{2}$ to generate $\mathrm{CaFeSiO}_{4}$ by $a(\mathrm{CaO})+b\left(\mathrm{SiO}_{2}\right)+c(\mathrm{FeO})=a \mathrm{CaO} \cdot b \mathrm{SiO}_{2} \cdot c \mathrm{FeO}(\mathrm{s})$, resulting in a poor dephosphorization performance of slag.

Author Contributions: Conceptualization, L.C. and J.L.; methodology, L.C. and H.X.; software, H.X.; validation, Y.W., Y.X., and C.L.; formal analysis, C.L.; investigation, L.C.; resources, J.L.; data curation, L.C.; writing—original draft preparation, L.C. and H.X.; writing—review and editing, L.C. and Y.W.; visualization, C.L.; supervision, J.L.; project administration, J.L.; funding acquisition, Y.X. All authors have read and agreed to the published version of the manuscript.

Funding: This research was funded by the National Natural Science Foundation and Steel Joint Research Fund of China BaoWu Steel Group Co., LTD, grant number U1960110, as well as the National Natural Science Foundation of China, grant number 52074003 and grant number 52074001.

Data Availability Statement: The data presented in this study are available on request from the corresponding author. The data are not publicly available due to the confidentiality agreement that we signed with the cooperative steelworks.

Conflicts of Interest: The authors declare no conflict of interest.

\section{References}

1. Zhou, Y.Y.; Yu, C.H.; Xu, J.B.; Feng, J. Experimental study on hot metal dephosphorizing pretreatment and direct steelmaking process in converter. Steelmaking 2004, 20, 40-43.

2. Wang, X.B.; Feng, M.X.; Zou, Z.S.; Zhao, G.G.; Liu, Z.X. Slag forming route and dephosphorization of BOF dephosphorizing pretreatment and direct Steelmaking. Iron Steel 2009, 44, 23-26. [CrossRef]

3. Li, J.; Huang, B.C.; Fang, Y.R.; Chen, B.Y.; Liu, L. Research on hot metal dephosphorizing pretreatment and direct steelmaking process in $100 \mathrm{t}$ converter. Iron Steel 2010, 45, 36-39.

4. Liu, L. Technological progress in converter steelmaking. Steelmaking 2000, 40, 1-5.

5. Ogawa, Y.; Yano, M.; Kitamura, S.; Hirata, H. Development of the continuous dephosphorization and decarburization process using BOF. Tetsu-to-Hagane 2001, 87, 21-28. [CrossRef]

6. Ogawa, Y.; Yano, M.; Kitamura, S. Development of the continuous dephosphorization and decarburization process using BOF. Steel Res. Int. 2003, 74, 70-76. [CrossRef]

7. Iwasaki, M.; Matsuo, M. Change and development of steelmaking technology. Nippon Steel Tech. Rep. 2011, 391, 88-93.

8. Kumakura, M. Advances in the refining technology and the future prospects. Nippon Steel Tech. Rep. 2012, 394, 4-11.

9. Iwasaki, M.; Matsuo, M. Improvement of hot metal dephosphorization technique. Nippon Steel Tech. Rep. 2012, $394,26-32$.

10. Hashimoto, T.; Iiboshi, H.; Kume, K. Improvement in production capacity at Oita Works. Nippon Steel Tech. Rep. 2012, 394, 84-90. 
11. Kobayashi, M.; Isobe, K.; Arai, M. Technical progress in steelmaking and casting for special bar and wire steel at Muroran Work. Nippon Steel Tech. Rep. 2012, 394, 119-124.

12. Li, H.B.; Lu, Y.C.; Zhu, G.H.; Wang, X.H. Development of 'Slag-Remaining+Double-Slag' BOF steelmaking technology in Shougang Co. In Advances in Molten Slags, Fluxes, and Salts: Proceedings of the 10th International Conference on Molten Slags; Springer: Cham, Switzerland, 2016; pp. 1177-1184.

13. Yang, X.; Sun, F.M.; Yang, J.L.; Liu, F.; Cheng, K.S.; Wang, J.H. Optimization of low phosphorus steel production with double slag process in BOF. J. Iron Steel Res. Int. 2013, 20, 41-47. [CrossRef]

14. Fang, Y.R.; Hang, B.C. Study on dephosphorization pretreatment process in $120 \mathrm{t}$ converter. In Proceedings of the 17th National Steelmaking Academic Conference, Hangzhou, China, 15-17 May 2013; pp. 112-118.

15. Wang, X.; Zou, Z.S. Theoretics study on demarcation point of dephosphorization pretreatment and direct steelmaking process in converter. China Metall. 2007, 17, 10-13.

16. Healy, G.W. New look at phosphorus distribution. J. Iron Steel Inst. 1970, 208, 664-668.

17. Tsukihashi, F.; Nakamura, M.; Orimoto, T.; Sano, N. Thermodynamics of phosphorus for the $\mathrm{CaO}-\mathrm{BaO}-\mathrm{CaF}_{2}-\mathrm{SiO}_{2}$ and CaO-Al ${ }_{2} \mathrm{O}_{3}$ systems. Tetsu-to-Hagané 1990, 76, 1664-1671. [CrossRef]

18. Liao, P.; Hou, Z.W.; Qin, Z.; Zhang, X.Z.; Qiu, S.T. Experimental study of double slag combined blowing converter blowing dephosphorization process. Iron Steel 2013, 48, 30-36.

19. Zhou, C.G.; Li, J.; Wu, H. Study on the temperature of first deslagging of double slag dephosphorization in converter. Iron Steel 2014, 49, 24-28.

20. Wang, W.; Sun, K.; Liu, H.T. Effects of different aluminum sources on morphologies and properties of ceramic floor tiles from red mud. Constr. Build. Mater. 2020, 241. [CrossRef] 